\title{
Teacher Leadership Effects on Student Achievement and Student Satisfaction: A Meta-Analysis of the Studies Published in Turkey and the USA
}

Sengül Uysal and Yilmaz Sarier
Ministry of National Education

\section{Abstract}

The growing emphasis on teacher leadership over the past decades has given rise to studies that investigate the direct and indirect effects on school improvement process and outcomes. This study aims to examine the effect of teacher leadership on student achievement and student satisfaction through a cross-cultural analysis of 22 published studies. The meta-analysis involved a comparison of the effects of teacher leadership on student achievement and student satisfaction in Turkey and the USA. The results indicated that the average effect of teacher leadership on student achievement is modest and positive (ES=.229), while it is strong and positive (ES=.639) on student satisfaction. The comparison between the two countries shows that the average effect of teacher leadership on student satisfaction is much stronger in Turkey than it is in the USA.

Key words: achievement; leadership; meta-analysis; satisfaction; teacher.

\section{Introduction}

Teacher leadership has become a defining characteristic of the recent efforts to professionalize teaching and reform schools (Smylie, 1995, p. 3). In the light of the literature reviewed, teacher leadership is to be promoted in order to increase the likelihood of school improvement (Lieberman \& Miller, 2004; Murphy, 2005; Smylie, 2010). Leithwood and his colleagues (1996) stated that the literature concerning school improvement consistently highlights that effective leaders exercise an indirect 
but powerful influence on schools' capacity to improve the achievement of students (Muijs \& Harris, 2003, p. 437).

Today, education is facing a big challenge, which is why schools need to improve and sustain their success. Teacher leadership has been shown to be central in achieving both school and classroom improvement. Even in dire circumstances, they support their development by increasing leadership capacity of teachers who are expected to support school and student success, by leading collaborative work through coaching, mentoring colleagues, improving learning environment and modelling effective teaching.

It is evident from the literature that the definition of 'teacher leadership' is vague, to a certain degree. Somewhat inevitably, therefore, there is some conceptual confusion over the exact meaning of teacher leadership (Muijs \& Harris, 2003, p. 434-438). Wasley (1991, p. 23) describes teacher leadership as "the ability to encourage colleagues to change, to do things they would not ordinarily consider without the influence of the leader". Similarly, Gehrke (1991) states that teacher leaders improve their teaching, provide curriculum development, take part in decision-making, support colleagues and deal with performance evaluation. According to Lieberman (1988), the main role of teacher leaders is to help colleagues state new ideas and encourage them to become leaders. As West and his colleagues (2000, p. 39) state:

If this leadership potential is to be realised, then it will have to be grounded in a commitment to learn and develop that inhabits the structures of schools as well as the classroom- it is likely that the school will conceive and act differently from the traditional explanations of leadership and structure.

A major motive for being interested in examining the relationship between teacher leaders and student academic and non-academic achievement is to advance academic education and highlight the crucial role of educators within this process. In general, leaders are widely accepted as having an indirect but powerful effect on school outcomes (Leithwood \& Jantzi, 1999). Effective leaders influence the quality of teaching and motivate both the pupils and colleagues, while consequently instigating school improvement (Sergiovanni, 2001). According to Hallinger and Hell (1998), quantitative studies on principal leadership concluded that principal leadership has an indirect effect on student achievement which is mediated by teachers. In other words, teachers are the primary factor affecting school outcomes.

The teachers' direct leadership in instruction creates an opportunity to play an important role in altering the environment to optimise student learning. Similarly, Katzenmeyer and Moller (2001) suggest that teacher leadership improves teacher expectation that results in better student learning. According to Ryan (1999), teachers have positive effects on student learning because they influence the instructional practices of colleagues and take part in decision-making. Besides this, for Ovando (1996), teacher leaders have positive effect on student learning via innovative learning 
environment. Pellicer and Anderson (1995) state that teachers help "teachers so that teachers can, in turn, better help students" (p. 22). Barth (1990) believes that all teachers have the ability to lead, suggesting the need for schools where students, parents, teachers and principals can all become teachers. The principal has a crucial role in fostering the conditions that facilitate teacher leadership skills (Buckner \& McDowelle, 2000). Even Boles (1992) finds that teacher leadership is shaped by the principal's support, strong organizational culture, and involvement in decision-making as well as the professional development of others.

One of the school's non-academic outcomes that is thought to be influenced by teacher leadership is student satisfaction. Satisfaction can be defined as the overall level of enjoyment. The word satisfaction is basically used in the theory of Hierarchy of Needs', by Abraham Maslow (1943). According to Maslow, satisfying a person's basic needs will let him reach higher levels of safety, love, belonging, esteem and self-actualization. Based on Maslow's theory, at school, teachers who are friendly, supportive, and who use the best teaching practices lead to an increase in student satisfaction (House, 2005; Suldo et al., 2009). On the other hand, satisfaction is an important aspect of student success, and high satisfaction is positively correlated with high achievement (Brown et al., 2004).

The main reason for addressing the concept of teacher leadership and student achievement with satisfaction is to investigate the relationship between them, using a cross-cultural meta-analysis of the published studies in Turkey and the USA, which can create a holistic view of the topic.

\section{Purpose of the Study}

The purpose of this study is to investigate the effects of teacher leadership on student achievement and student satisfaction in Turkey and the USA. Meta-analysis is used to quantify the effect of teacher leadership on student achievement and student satisfaction. The country in which the study was conducted was used as the moderator variable in order to explain the variation in statistical differences.

\section{Research Hypotheses}

H1 Teacher leadership has a positive effect on student achievement and student satisfaction.

H2 The country (Turkey and the USA) in which the studies included in the research were carried out is a moderation variable for the positive effect of teacher leadership on student achievement and student satisfaction.

\section{Methodology}

Meta-analysis is a method of combining the results of multiple, independent studies on a specific subject, and applying the statistical analysis of the research findings obtained. This method provides quantitative data, summarizing the results of various 
studies to researchers who make the final conclusion (Chin, 2007; Lipsey \& Wilson, 2001; Robinson, Lloyd, \& Rowe, 2008).

Meta-analysis aims to reach all published or unpublished data (dissertations, master theses, articles, proposals, books) on the subject matter. However, in this study, only dissertations, master theses and articles published in refereed journals are included. The literature review was carried out in YOK (Council of Higher Education in Turkey), ULAKBIM (Turkish Academic Network and Information Center), ProQuest and EBSCO academic databases containing abstracts and contents of quantitative studies on the topics of teacher leadership, student achievement and student satisfaction. The key words used in searching the studies were 'leader,' 'leadership', 'teacher leader', 'student achievement' and 'student satisfaction'. In addition, the release date of research studies (between January 2000 and December 2017), the effect of teacher leadership on student achievement and student satisfaction, statistical data of sample size, Pearson's $r$ for calculation of effect size and the sample within USA and Turkey were used in the selection of the studies included in the survey.

A framework for developing a coding scheme for meta-analysis was needed to categorize publications. A coding book was created in order to extract data from the research literature. The studies examined were grouped by evaluating teacher leadership approaches that are identified in the survey. Following the expert opinions, moderator variables were identified and 34 effect sizes were included in the study. Some studies were excluded because the same data sets were used in multiple publications. However, several publications included in the research had examined more than one leadership approach. Due to this reason, the dataset used in the 22 publications was determined to be 34 in total. The flowchart for the selection of studies included is summarized in Figure 1.

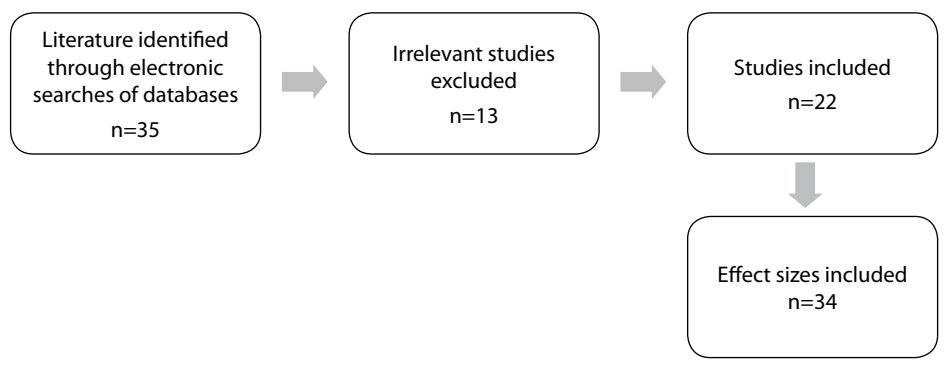

Figure 1. Flow chart showing selection of studies for meta-analysis.

The effect size can be conceptualized as the mean difference between groups, and used in determining the strength, magnitude and direction of the relationship (Borenstein, Hedges, Higgins, \& Rothstein, 2009). For Cohen, Manion, and Morrison (2007, p. 221), the effect size values, based on the correlation, are interpreted as: $0 \leq$ effect size $<.10$ - small effect; $.10 \leq$ effect size $<.30$ - modest effect; $.30 \leq$ effect size $<.50$ - moderate effect; $.50 \leq$ effect size $<.80$ - strong effect; effect size $\geq .80$ - very strong effect. 
There are two basic models of meta-analysis: fixed-effects model and randomeffects model. When deciding on which model to use, it is necessary to look at the features of the investigations involved in the meta-analysis (Borenstein, Hedges, Higgins, \& Rothsteini, 2009; Hedges \& Olkin, 1985; Kulinskaya, Morgenthaler, \& Staudte, 2008). The fixed-effects model is estimated using the maximum likelihood (all studies included are functionally identical), and calculating the effect size for a defined population. By contrast, it is unlikely that all the studies are functionally equivalent, and generalizations can be made to a larger population where the random-effects model is more justifiable than the fixed-effects model (Karadağ, Bektaş, Çoğaltay, \& Yalçın, 2015). In the study, the fixed-effects model was used first. It was observed that homogeneity could not be achieved in the fixed-effects model (depending on the results of heterogeneity test, the research is not equal in terms of functionality, $\left(\mathrm{Q}>\mathrm{X}^{2}\right)$ (see Table 3) and then the random-effects model was applied. A significance level of 0.05 was chosen for all statistical calculations in the study.

Moderator analysis is a method that allows testing the differences between the mean effect sizes of variables (moderators) and the direction of differences between subgroups. The statistical significance of the difference between the moderator variables is tested by the $\mathrm{Q}$ statistical method developed by Hedges and Olkin (1985). In this method, $\mathrm{Q}$ is divided into $\mathrm{Q}$ between [Qb] and $\mathrm{Q}$ within [Qw], and the analyses are carried out on these two different Qs. Qw tests the homogeneity of the moderator variable in itself, while $\mathrm{Qb}$ tests the homogeneity between the groups (Borenstein, Hedges, Higgins, \& Rothstein 2009; Hedges \& Olkin, 1985; Kulinskaya, Morgenthaler, \& Staudte, 2008). In this study, only the Qb values were used for the statistical significance of the differences between moderators.

\section{Results}

In this section, descriptive analysis of the studies was performed, then the data obtained were combined using the meta-analysis. The data related to the studies are presented in the following table using the frequency and percentage values. Table 1 shows the descriptive analysis of the studies examined in the research.

Table 1

Descriptive analysis of the studies included in the meta-analysis (f\&\%)

\begin{tabular}{llcc}
\hline & & Frequency (f) & Percentage (\%) \\
\hline Country in which the research & Turkey & 26 & 76.5 \\
was published & USA & 8 & 23.5 \\
Year in which the research was & $2000-2008$ & 6 & 17.6 \\
published & $2009-2017$ & 28 & 82.4 \\
\multirow{4}{*}{ Publication type of research } & Dissertation & 20 & 58.8 \\
& Article & 14 & 41.2 \\
The level of education & Primary education & 18 & 52.9 \\
& Secondary education & 16 & 47.1 \\
\hline
\end{tabular}


Table 1 shows that 26 studies were conducted in Turkey, while only 8 studies were carried out in the USA. The date of distribution of the studies reveals that most of the studies (82.3\%) were conducted in 2009 and later. This shows that in recent years, teacher leadership has become a topic of interest for researchers. Approximately $60 \%$ of the studies are produced in the form of dissertations.

Table 2

Primary studies included in the meta-analysis

\begin{tabular}{|c|c|c|c|c|c|c|c|c|c|c|c|}
\hline No. & Year & Author & Country & $\mathrm{n}$ & $r$ & No. & Year & Author & Country & $\mathrm{n}$ & $r$ \\
\hline 1 & 2000 & Yıldırım, İ. & Turkey & 545 & .281 & 18 & 2013 & Dağdelen, S. & Turkey & 402 & .13 \\
\hline 2 & 2002 & Yılmaz, K. & Turkey & 1469 & .71 & 19 & 2013 & Dağdelen, S. & Turkey & 402 & .16 \\
\hline 3 & 2003 & Burr, B. W. & USA & 500 & .258 & 20 & 2013 & Dağdelen, S. & Turkey & 402 & .30 \\
\hline 4 & 2005 & Korkmaz, M. & Turkey & 791 & .52 & 21 & 2013 & Dağdelen, S. & Turkey & 402 & .25 \\
\hline 5 & 2006 & Yıldırım, İ & Turkey & 962 & .173 & 22 & 2013 & Dağdelen, S. & Turkey & 402 & .22 \\
\hline 6 & 2007 & $\begin{array}{l}\text { Erdoğdu, } \\
\text { M.Y. }\end{array}$ & Turkey & 191 & .348 & 23 & 2013 & Dağdelen, S. & Turkey & 402 & .29 \\
\hline 7 & 2010 & $\begin{array}{l}\text { Erden, M., } \\
\text { Akgül, S. }\end{array}$ & Turkey & 292 & .56 & 24 & 2013 & Bahçetepe, Ü. & Turkey & 1054 & .073 \\
\hline 8 & 2010 & Özdemir, F. & Turkey & 199 & .26 & 25 & 2013 & Bahçetepe, Ü. & Turkey & 1054 & .065 \\
\hline 9 & 2010 & Özdemir, F & Turkey & 2917 & .02 & 26 & 2013 & Bahçetepe, Ü. & Turkey & 1054 & .089 \\
\hline 10 & 2010 & Demirtaş, Z. & Turkey & 784 & .098 & 27 & 2013 & Bahçetepe, Ü. & Turkey & 1054 & .11 \\
\hline 11 & 2010 & Demirtaş, Z. & Turkey & 452 & .079 & 28 & 2014 & Günal, Y. & Turkey & 4472 & .372 \\
\hline 12 & 2011 & $\begin{array}{l}\text { Özdemir, S., } \\
\text { Sezgin, F. }\end{array}$ & Turkey & 3409 & .64 & 29 & 2014 & Günal, Y. & Turkey & 4472 & .35 \\
\hline 13 & 2011 & Qazi, A. A. & USA & 212 & .14 & 30 & 2014 & Bulduklu, E. & Turkey & 594 & .116 \\
\hline 14 & 2012 & Norton, L. F. & USA & 689 & .490 & 31 & 2017 & Clark, J. L. & USA & 376 & -.071 \\
\hline 15 & 2012 & Ateş, B. & Turkey & 428 & .771 & 32 & 2017 & Garza, S. S. & USA & 228 & .173 \\
\hline 16 & 2013 & $\begin{array}{l}\text { Bektaş, F., } \\
\text { Nalçacl, A. }\end{array}$ & Turkey & 598 & .007 & 33 & 2017 & Garza, S. S. & USA & 228 & .157 \\
\hline 17 & 2013 & Sugg, S. & USA & 2292 & -.015 & 34 & 2017 & Garza, S. S. & USA & 228 & .173 \\
\hline
\end{tabular}

According to Table 2, the direction of the effect sizes is positive for most of the studies (94.1\%) included in the research.

The effect size value (mean $r$ ) is calculated in order to determine the strength and direction of the relationship between teacher leadership and student achievement with satisfaction (Table 3). The correlation coefficient ( $r$ ) is converted into the Fischer's $\mathrm{z}$ value (Hedges \& Olkin, 1985), stated in Table 3. Once the effect size is calculated, then it is interpreted using Cohen's criterion values. According to the results of metaanalysis using the fixed-effects size model, teacher leadership value regarding the effect on student achievement was calculated as .249 for Turkey and .115 for the USA. The result for both is .229. In addition, the value for satisfaction is .691 for Turkey and .169 for the USA. For both Turkey and the USA, the effect size value was calculated as .639. The findings support $\mathrm{H1}$, which states that teacher leadership has a positive 
effect on student achievement and student satisfaction. Depending on the results of heterogeneity test, the research is not equal in terms of functionality, so the randomeffects model was applied in the following meta-analysis processes $\left(\mathrm{Q}>\mathrm{X}^{2}\right)$.

Table 3

Correlation between teacher leadership, student achievement and student satisfaction: The result of meta-analysis

\begin{tabular}{|c|c|c|c|c|c|c|c|c|}
\hline \multirow{2}{*}{ Concept } & \multirow{2}{*}{ Country } & \multirow{2}{*}{$f$} & \multirow{2}{*}{$\begin{array}{c}\text { ES } \\
\text { (Fischer's z) }\end{array}$} & \multicolumn{2}{|c|}{$95 \%$ confidence interval } & \multirow{2}{*}{$\mathrm{Q}_{B}$} & \multirow{2}{*}{$x^{2}$} & \multirow{2}{*}{$\mathrm{p}$} \\
\hline & & & & Lower limit & Upper limit & & & \\
\hline \multirow{3}{*}{ Achievement } & Turkey & 21 & .249 & .236 & .262 & 894.38 & 31.41 & .000 \\
\hline & USA & 5 & .115 & .085 & .146 & 184.39 & 9.48 & .000 \\
\hline & General & 26 & .229 & .217 & .241 & 1140.13 & 37.65 & .000 \\
\hline \multirow{3}{*}{ Satisfaction } & Turkey & 5 & .691 & .666 & .716 & 296.09 & 9.48 & .000 \\
\hline & USA & 3 & .169 & .094 & .245 & .04 & 5.99 & .980 \\
\hline & General & 8 & .639 & .615 & .663 & 461.42 & 14.06 & .000 \\
\hline \multirow{3}{*}{$\begin{array}{l}\text { Achievement } \\
\text { and Satisfac- } \\
\text { tion }\end{array}$} & Turkey & 26 & .341 & .329 & .352 & 2129.94 & 37.65 & .000 \\
\hline & USA & 8 & .123 & .095 & .152 & 186.12 & 14.06 & .000 \\
\hline & General & 34 & .310 & .300 & .321 & 2509.13 & 47.40 & .000 \\
\hline
\end{tabular}

Table 4

Meta-analysis for country as a moderator

\begin{tabular}{|c|c|c|c|c|c|c|c|c|}
\hline \multirow[t]{2}{*}{ Concept } & \multirow[t]{2}{*}{ Country } & \multirow[t]{2}{*}{$f$} & \multirow{2}{*}{$\begin{array}{c}\text { ES } \\
\text { (Fischer's z) }\end{array}$} & \multicolumn{2}{|c|}{$95 \%$ confidence interval } & \multicolumn{3}{|c|}{$\begin{array}{c}\text { Heterogeneity } \\
\text { test }\end{array}$} \\
\hline & & & & Lower limit & Upper limit & $\mathrm{Q}_{\mathrm{B}}$ & $x^{2}$ & $\mathrm{p}$ \\
\hline \multirow{3}{*}{ Achievement } & Turkey & 21 & .252 & .162 & .342 & \multirow{3}{*}{.39} & \multirow{3}{*}{3.84} & \multirow{3}{*}{.531} \\
\hline & USA & 5 & .171 & -.066 & .409 & & & \\
\hline & General & 26 & .242 & .158 & .326 & & & \\
\hline \multirow{3}{*}{ Satisfaction } & Turkey & 5 & .488 & .240 & .736 & \multirow{3}{*}{5.80} & \multirow{3}{*}{3.84} & \multirow{3}{*}{.016} \\
\hline & USA & 3 & .169 & .094 & .245 & & & \\
\hline & General & 8 & .196 & .124 & .268 & & & \\
\hline
\end{tabular}

The results support $\mathrm{H} 2$, which asserted that country (Turkey and the USA) in which the studies included in the research were published is a moderation variable for the positive effect of teacher leadership on student achievement and student satisfaction (Table 4). It was found that country as a moderating variable explained the excess effect sizes variability, and the effect size in Turkey for both achievement and satisfaction $(.252 / .488)$ is significantly higher than the effect size in the USA (.171/.169).

\section{Findings Related to Publication Bias}

It is really crucial to control the publication bias in meta-analysis studies. Publishing bias is in fact based on the assumption that all of the research on a topic has not been published. Since it is not deemed worth specifically to publish investigations in which statistically significant relationships cannot be found or low levels of relations are identified, this affects the total effect size level negatively and increases the mean effect 
size prejudicially (Borenstein, Hedges, Higgins, \& Rothstein, 2009). In this sense, the likelihood of publication bias is taken into account in meta-analysis studies. A number of calculation methods are used to provide a statistical answer as to whether there is publication bias in meta-analysis. The funnel plot method is the first of these. The shape provided by this method reveals whether the studies obtained by the subjective evaluation are influenced by the publication bias. In this study, the funnel graph of the studies included in meta-analysis is shown in Figure 2.

Funnel Plot of Standard Error by Fisher's Z

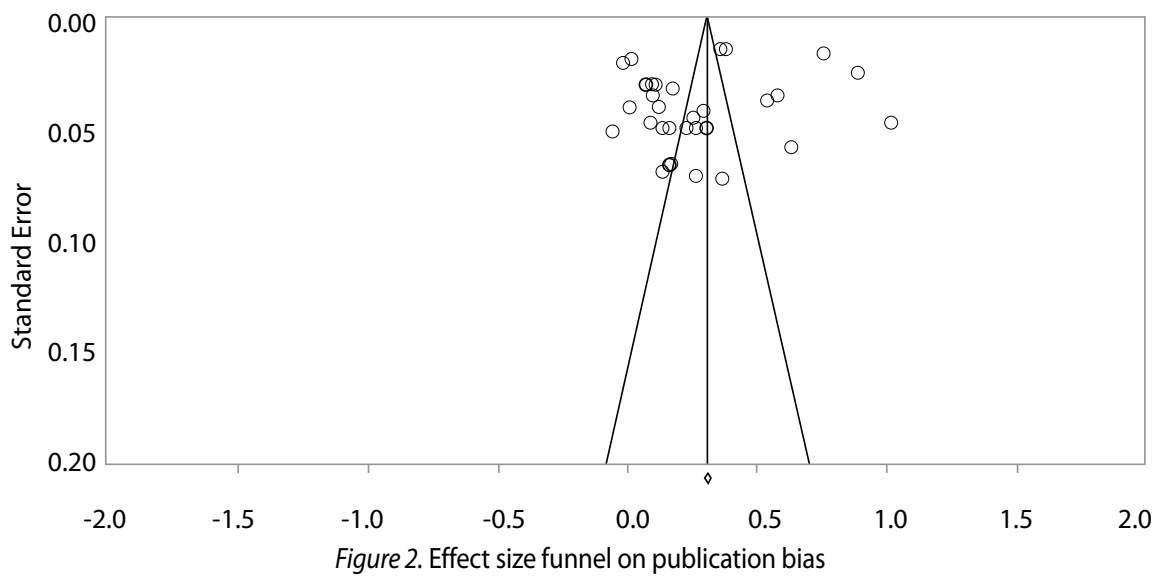

In Figure 2, no evidence of publication bias was observed in the studies included in meta-analysis. It is expected that the funnel graph will be significantly asymmetric in the bias of publication. Concentrations on the one side of the line showing the average effect size, especially in the lower parts of the funnel, indicate the possibility of publication bias. There is no evidence of bias in the publication of 34 studies involved in meta-analysis of the research.

Although there is no evidence of bias in the funnel graph, the results of the Trim and Fill test are presented in Table 5 to assess the effect size of the meta-analysis with random effects model in terms of publication bias.

Table 5

The results of Duval and Tweedie's Trim and Fill test

\begin{tabular}{lccccc}
\hline & Excluding & Point & \multicolumn{2}{c}{ Confidence Interval } & \multirow{2}{*}{ Q } \\
\cline { 4 - 5 } & study & estimate & Lower limit & Upper limit & \\
\hline Observed variable & & .268 & .173 & .364 & \multirow{2}{*}{2509.135} \\
Adjustment values & 0 & .268 & .173 & .364 & \\
\hline
\end{tabular}

As shown in Table 6, there is no difference between the magnitude of the observed effect and that of the virtual effect. An analysis of the Classic Fail-Safe $\mathrm{N}$ was also used to analyse the publication bias in the study. The results of the analysis are shown in Table 6. 
Table 6

The results of Classic Fail-Safe N analysis

\begin{tabular}{lr}
\hline The power of meta-analysis & \\
\hline Z-value & 46.67 \\
p-value & .00 \\
Alpha value & .05 \\
Alpha value for Z & 1.96 \\
Number of observed studies & 34 \\
Number of missing studies that would bring p-value to > alpha & 9245 \\
\hline
\end{tabular}

According to the findings obtained, 9,245 individual studies should be added to the analysis in order to override the result of the meta-analysis study $(\mathrm{p}<.05)$. This information shows that there is no bias in this meta-analysis study.

\section{Discussion and Conclusion}

The purpose of this study was to examine the effects of teacher leadership on student achievement and satisfaction. The meta-analysis results revealed that teacher leadership has a moderate positive effect on student achievement and a strong positive effect on student satisfaction. In Turkey, the effects of teacher leadership on student satisfaction are much stronger than in the USA.

Before discussing the results of this study, it is necessary to explain the limitations. Firstly, only 22 studies were included in the analysis as the remaining studies did not have the necessary data for calculating the average size. Secondly, more research is needed to conduct an analysis of other non-academic outcomes relating to students, besides satisfaction.

It can be seen through literature review that teacher leadership has an effect on student achievement (Lambert, 1998; Leiberman \& Miller, 2004; Murphy, 2005; Smylie, 2010; Spillane, 2006). Since teachers have information about the learning environment in classrooms, they are at an advantage to produce effective solutions (Sinclair, 1992). Teachers even play an important role in the development of a learning environment by solving instructional problems and create a supportive school culture (Francis, Hirsch, \& Rowland, 1994). In addition, Stigler and Hiebert (1999) explain that teachers who work collaboratively with colleagues, principals, and other stakeholders, improve student learning. Allen and his colleagues (2011) stated the positive effect of teacher leaders on student achievement. Leithwood and Mascall (2008) found similar positive results of teacher leadership behaviours. In addition, Silns and Mumford (2002) suggest that empowering the educators is necessary for improving student achievement.

So what makes it possible to realize the full potential of teacher leaders? The answer is: the school principal. School principals are responsible for sharing or distributing the leadership responsibilities. Although many research studies document that principal 
leadership has influence on school success (Leithwood, Jantzi, \& Steinbach 1999; Marzano, Waters, \& McNulty, 2005), teacher leaders have been recently supported against the traditional models of leadership falling short in school improvement (Copland, 2003). As Angelle and DeHart (2010) state, "Principals must change their perception of the teacher from a follower to a facilitator" (p. 8).

Teacher satisfaction and student satisfaction have been positively correlated with student achievement (Caprara, Barbranelli, Steca, \& Malone, 2006; Lim, Kim, Chen, \& Ryder, 2008). Besides this, a low level of satisfaction results in low student academic achievement (Brown, Anfara, \& Roney, 2004; Van Houtte, 2006). Supportive teachers who use diverse teaching methods help increase students' success, which results in higher student satisfaction (Suldo et al., 2009, p. 80). In another study performed by Baird (1973), the findings showed that teachers working collaboratively with students develop both student achievement and satisfaction.

The comparison between the results obtained from Turkey and USA showed that the average effect size is greater in Turkey. The centralized education system in Turkey could be one of the major factors at play within this distinction. Although teacher leadership is a commonly researched topic in Turkey, the concept is not applicable. Taking into consideration the dynamics of teacher leadership, participation in decision-making, instruction design and curriculum development, it could be crucial to support teacher leaders in order to optimize the effectiveness of schools.

Although it is clear from the literature that teacher leadership is crucial for effective schools, there are barriers to be overcome. In order to develop teacher leadership, we recommend:

'Top-down' management maintaining bureaucratic and hierarchical structure needs to be replaced by the organizations introducing shared leadership.

Common core standards may be defined to allow teachers to participate in decisionmaking regarding curriculum and instruction.

Programmes and workshops for professional development including skills such as leading groups, collaborative work and mentoring would be recommended to develop teacher leadership.

\section{References}

${ }^{*}$ Ahmed, I., \& Qazi, T. F. (2011). Do students' personality traits moderate relationship of teacher's leadership style and students' academic performance? Empirical evidence from Institute of higher learning. International Journal of Academic Research, 3(4), 393-400.

Allen, J., Pianta, R., Gregory, A., Mikami, A., \& Lun, J. (2011). An interaction-based approach to enhancing secondary school instruction and student achievement. Science, 333(6045), 1034-1037. https://doi.org/10.1126/science. 1207998 
Angelle, P. S., \& DeHart, C. (2010). A four factor model of teacher leadership: Construction and testing of the Teacher Leadership Inventory. Paper presented at the annual meeting of the American Educational Research Association, Denver, CO.

${ }^{\star}$ Ateş, B. (2012). Investigation of some variables of secondary school students' social support perceptions. Academic Sight, 30(2),1-16.

*Bahçetepe, Ü. (2013). The relation between the 8 th grade students' academic achievement and the school climate they perceive. (Master's thesis). İstanbul: İstanbul University.

Baird, L. (1973). Teaching styles: An exploratory study of dimensions and effects. Journal of Educational Psychology, 64(1), 15-21. https://doi.org/10.1037/h0034058

Barth. R. S. (1990). Improving schools from within. San Francisco: Jossey-Bass Publishers.

${ }^{\star}$ Bektaş, F., \&Nalçac1, A. (2013). The relationship between school climate and student achievement. International Journal of Euroasia Social Sciences, 4(13), 1-13.

Boles, K. C. (1992). School Restructuring by Teachers: A Study of the Teaching Project at the Edward Devotion School. Paper presented at the Annual Meeting of the American Educational Research Association, San Francisco, CA, April 1992.

Borenstein, M., Hedges, L. V., Higgins, J. P. T., \& Rothstein, H. R. (2009). Introduction to MetaAnalysis. United Kingdom: John Wiley \& Sons. https://doi.org/10.1002/9780470743386

Brown, K. M., Anfara, V. R., \& Roney, K. (2004). Student achievement in high performing, suburban middle schools and low performing, urban middle schools: Plausible explanations for the differences. Urban Society, 36(4), 428-456. https://doi. org/10.1177/0013124504263339

Buckner, K.C., \&McDowelle, J. (2000). Developing Teacher Leaders: Providing Encouragement, Opportunities, Support NASSP Bulletin, 84, no 616. https://doi. org/10.1177/019263650008461607

${ }^{\star}$ Bulduklu, E. (2014). The relationship between instructional leadership of principals, teachers' self-efficacy and student achievement. (Doctoral dissertation). Konya: Mevlana University.

${ }^{\star}$ Burr, W. B. (2003). Teacher leadership: Is it related to student achievement? (Doctoral dissertation). Texas A \& M University-Commerce.

Caprara, G., Barbranelli, C., Steca, P., \& Malone, P. (2006). Teachers' self-efficacy beliefs as determinants of job satisfaction and students' academic achievement: A study at the school level. Journal of School Psychology, 44(6), 473-490. https://doi.org/10.1016/j.jsp.2006.09.001

Chin, J. M-C. (2007). Meta-analysis of transformational school leadership effects on school outcomes in Taiwan and the USA. Asia Pacific Education Review, 8(2), 166-177. https:// doi.org/10.1007/BF03029253

${ }^{\star}$ Clark, J. L. (2017). The Self-Perception of Leadership Efficacy of Teachers and the Effects on Student Achievement. (Doctoral dissertation). Eastern Michigan University, USA.

Cohen L., Manion, L., \& Morrison, K. (2007). Research Methods in Education. London: Routledge-Falmer. https://doi.org/10.4324/9780203029053

Copland, M. A. (2003). Leadership of inquiry: building and sustaining capacity for school improvement. Educational Evaluation and Policy Analysis, 25(4), 375-395. https://doi. org/10.3102/01623737025004375 
Uysal and Sarier: Teacher Leadership Effects on Student Achievement and Student Satisfaction: A Meta-analysis ...

* Dağdelen, S. (2013). Investigation of the relationship between biology teachers' interpersonal behaviour, classroom learning environment and student academic achievement. (Master's thesis). Istanbul: Marmara University.

*Demirtaş, Z. (2010a). The relationship between school culture and student achievement. Education and Science, 35(158), 3-13.

${ }^{*}$ Demirtaş, Z. (2010b). The relationship in high schools between school culture and student achievement. Mustafa Kemal University Journal of Social Sciences Institute, 7(13),208-223.

* Erden, M., \&Akgül, S. (2010). Predictive power of math anxiety and perceived social support from teacher for primary students' mathematics achievement. Journal of Theory and Practice in Education, 6(1), 3-16.

*Erdoğdu, M. Y. (2007). The relationship between parents' attitudes, teacher behavior and student academic achievement. Sakarya University Journal of Education, 13, 23-33.

Francis, S., Hirsch, S., \& Rowland, E. (1994). Improving school culture through study groups. Journal of Staff Development. 13, 12-15.

${ }^{*}$ Garza, S.S. (2017). Stem high school teachers' leadership style and the relationship of their Hispanic students' school engagement as perceived by the student. (Doctoral dissertation). Lake University, USA.

${ }^{*}$ Günal, Y. (2014). The relationship between effective school variables and student achievement and school accountability. (Doctoral dissertation). Ankara: Ankara University.

Hallinger, P., \& Heck, R. H. (1998). Exploring the principal's contribution to school effectiveness: 1980-1995. School Effectiveness and School Improvement, 9, 157-191. https:// doi.org/10.1080/0924345980090203

Hedges, L. V., \& Olkin, I. (1985). Statistical method for meta-analysis. United Kingdom: Academic Press.

Karadağ, E., Bektaş, F., Çoğaltay, N., \&Yalçın, M. (2015). The effect of educational leadership on students' achievement: a meta-analysis study. Asia Pacific Education Review, 16(1), 7993. https://doi.org/10.1007/s12564-015-9357-x

Katzenmeyer, M., \& Moller, G. (2001). Awakening the Sleeping Giant. Helping Teachers Develop as Leaders. California: Thousand Oaks, Corwin Press.

*Korkmaz, M. (2005). The relationship between organizational health and student achievement in primary schools. Educational Administration: Theory and Practice, 44, 529-548.

Kulinskaya, E., Morgenthaler, S., \& Staudte, R. G. (2008). Meta-analysis: a guide to calibrating and combining statistical evidence. London: John Wiley \& Son. https://doi. org/10.1002/9780470985533

Lambert, L. (1998). Building leadership capacity in schools. Alexandria, VA: ASCD

Leithwood, K., \& Jantzi, D. (1998). Distributed Leadership and Student Engagement in School. Paper Presented at the Annual Meeting of the American Educational Research Association, San Diego, CA, April 1998.

Leithwood, K., \& Mascall, B. (2008). Collective leadership effects on student achievement. Educational Administration Quarterly, 44(4), 529-561. https://doi. org/10.1177/0013161X08321221

Lieberman, A. (1988). Teachers and Principals: Turf, Tension and New Tasks. Phi Delta Kappan, 69, 648-653. 
Lieberman, A., \& Miller, L. (2004). Teacher leadership. San Francisco, CA: Josey-Bass.

Lim, J., Kim, M., Chen, S., \& Ryder, C. (2008). An empirical investigation of student achievement and satisfaction in different learning environments. Journal of Instructional Psychology, 35(2), 113-119.

Lipsey, M. W., \& Wilson, D. B. (2001). Practical meta-analysis. Thousand Oaks, CA: SAGE.

Marzano, R. J., Waters, T., \& McNulty, B. A. (2005). School leadership that works. Alexandria, VA: Association for Supervision and Curriculum Development.

Maslow, A. (1943). A theory of human motivation. Psychological Review, 50, 370-396. https:// doi.org/10.1037/h0054346

Muijs, D., \& Harris, A. (2003). Teacher leadership-Improvement through empowerment. Educational Management \& Administration, 31(4), 437-448. https://doi. org/10.1177/0263211X030314007

Murphy, J. (2005). Connecting teacher leadership to school improvement. Thousand Oaks, CA: Corwin.

${ }^{\star}$ Norton. L. F. (2012). Teacher leadership style and student engagement in the middle school classroom. (Doctoral dissertation). Dallas Baptist University, USA.

Ovando, M. (1996). Teacher Leadership: Opportunities and Challenges. Planning and Changing, 27(1/2), 30-44.

*Özdemir, F. (2010). Achievements in PISA 2003 in high schools and Kanuni High School. (Master's thesis). Ankara: Hacettepe University.

*Özdemir, S., \& Sezgin, F. (2011). Primary School Students' Perceptions of Principal and Teacher Support, Perceived Violence, and School Satisfaction. Inonu University Journal of the Faculty of Education, 12(2), 181-199.

Pellicer, L. O., \& Anderson, L. W. (1995). A handbook for teacher leaders. Thousand Oaks, CA: Corwin Press.

Robinson, M. J. V., Lloyd, C. A., \& Rowe, K. J. (2008). The impact of leadership on student outcomes: An analysis of the differential effects of leadership types. Educational Administration Quarterly, 44(5), 635-674. https://doi.org/10.1177/0013161X08321509

Ryan, S. (1999). Principals and teachers leading together. Paper presented at the annual meeting of the American Educational Research Association. Montreal, Quebec, Canada.

Sickler, J. L. (1988). Teachers in charge: Empowering the professionals. Phi Delta Kappan, 69, 354-356, 375-376.

Sergiovanni, T. J. (1999). Refocusing Leadership to Build Community. The High School Magazine, 12-15.

Silns, H., \& Mulford, B. (2002). Leadership and school results. Second international handbook of educational leadership and administration. The Netherlands: Kluwer Press. https://doi. org/10.1007/978-94-010-0375-9_21

Sinclair, R. (1992). The National Coalition problem solving process. Workshop presentation. National Coalition for Equality in Education Facilitators and Superintendents Meeting, October, 1992, Vail, CO.

Smylie, M. A. (2010). Continuous school improvement. Thousand Oaks, CA: Corwin.

Smylie, M.A. (1995). New perspectives on teacher leadership. The Elementary School Journal, 96(1), 3-7. https://doi.org/10.1086/461811 
Spillane, J. (2006). Distributed leadership. San Francisco, CA: Jossey-Bass.

Stigler, J. W., \& Hiebert, J. (1999). The teaching gap: Best ideas from the world's teachers for improving education in the classroom. New York: Free Press.

*Sugg, S. A. (2013). The Relationship Between Teacher Leadership and Student Achievement. (Online Theses and Dissertations). Retrieved from https://encompass.eku.edu/etd/138

Suldo, S., Friedrich, A., White, T., Farmer, J., Minch, D., \& Michalowski, J. (2009). Teacher support and adolescents' subjective well-being: A mixed-methods investigation. School Psychology Review, 38(1), 67-85.

Van Houtte, M. (2006). Tracking and teacher satisfaction: Role of study culture and trust. Journal of Educational Research, 99(4), 247-254. https://doi.org/10.3200/JOER.99.4.247-256

Wasley, P. A. (1991). Teachers Who Lead: The Rhetoric of Reform and the Realities of Practice. New York: Teachers College Press.

West, M. Jackson, D. Harris, A., \& Hopkins, D. (2000). Leadership for School Improvement. In K. Riley, \& K. Seashore-Louis (Eds.), Leadership for Change (pp. 35-47). London: Routledge Falmer Press.

* Yildırım, İ. (2000). Predictors of academic achievement: loneliness, test anxiety and social support. Hacettepe University Journal of Education, 18, 167-176.

* Yildırım, İ. (2006). Daily hassles and social support as predictors of academic achievement. Hacettepe University Journal of Education, 30, 258-267.

* Yilmaz, K. (2002). A study of leadership behaviors of primary school's administrators, the pupil control ideology as perceived by teachers and the quality of school life as perceived by students. (Master's thesis). Eskişehir: Eskişehir Osmangazi University.

\section{Sengül Uysal}

Ministry of National Education

Odunpazarı District Directorate of National Education, Bureau of Projects

Akarbaşı Neighborhood, Ada Street

NO: 3526020 Eskişehir, Turkey

sengultokgoz70@gmail.com

\section{Yilmaz Sarier}

Ministry of National Education

Odunpazarı District Directorate of National Education, Bureau of Projects

Akarbaşı Neighborhood, Ada Street

NO: 3526020 Eskişehir, Turkey

yilmazsarier@yahoo.com 


\section{Utjecaj nastavničkog vodstva na postignuća učenika i njihovo zadovoljstvo: metaanaliza studija objavljenih u Turskoj i Sjedinjenim Američkim Državama}

\section{Sažetak}

Na nastavničko se vodstvo posljednjih nekoliko desetljeća stavlja sve veći naglasak, što je rezultiralo velikim brojem studija u kojima se ispituju izravni i neizravni utjecaji nastavničkog vodstva na proces unapređenja škole i ishode učenja. U ovoj se studiji ispituje utjecaj nastavničkog vodstvo na postignuća učenika i njihovo zadovoljstvo međukulturnom analizom 22 objavljene studije. Metaanalizom je obuhvaćena usporedba utjecaja nastavničkog vodstva na postignuća učenika $i$ zadovoljstvo učenika u Turskoj i SAD-u. Rezultati pokazuju da je prosječan utjecaj nastavničkog vodstva na postignuća učenika umjeren i pozitivan (ES=0,229), a da je njegov utjecaj na zadovoljstvo učenika jak i pozitivan (ES=0,639). Usporedba dviju država pokazuje da je prosječan utjecaj nastavničkog vodstva na zadovoljstvo učenika puno veći u Turskoj nego u SAD-u.

Ključne riječi: metaanaliza; nastavnik; postignuća; vodstvo; zadovoljstvo.

\section{Uvod}

Nastavničko vodstvo postalo je ključan pojam u nastojanjima da se nastavni proces profesionalizira i da se provede reforma školstva (Smylie, 1995, str. 3). Kako pokazuje pregled literature, nastavničko vodstvo treba poticati kako bi se povećali izgledi za unapređenje škola (Lieberman i Miller, 2004; Murphy, 2005; Smylie, 2010). Leithwood i kolege (1996) naveli su da literatura koja se bavi unapređenjem škole sustavno naglašava da učinkoviti vođe imaju neizravan, ali snažan utjecaj na sposobnost škole da poboljša postignuća svojih učenika (Muijs i Harris, 2003, str. 437).

U današnje vrijeme obrazovanje je suočeno s velikim izazovom, pa zbog toga škole moraju unaprijediti svoja postignuća i održavati razinu uspješnosti. Pokazalo se da je nastavničko vodstvo ključno za ostvarivanje napretka i u školi i u razredu. 
Čak i u teškim uvjetima škole bi se trebale razvijati tako da podržavaju i povećavaju upravljačke sposobnosti nastavnika. Od njih se očekuje da podržavaju rad škole i potiču uspjeh učenika: provedbom suradničkoga rada, mentoriranjem kolega, unapređenjem okruženja za učenje i modeliranje učinkovitog nastavnog procesa.

U literaturi se može vidjeti da je definicija pojma nastavničko vodstvo u određenoj mjeri nejasna. U određenoj su mjeri zbog toga neizbježne konceptualne nejasnoće u vezi s točnim značenjem pojma nastavničko vodstvo (Muijs i Harris, 2003, str. 434438). Wasley (1991, str. 23) opisuje nastavničko vodstvo kao „sposobnost poticanja kolega na promjene, da čine ono što inače ne bi učinili bez utjecaja vođe". Slično tome, Gehrke (1991) navodi da nastavnici koji su vođe unapređuju vlastiti način poučavanja, doprinose razvoju kurikula, sudjeluju u procesu donošenja odluka, pružaju podršku kolegama i sudjeluju u procjeni njihova rada. Prema Liebermanu (1988), glavna je uloga nastavnika vođa pomoći kolegama da iznose nove ideje i potaknuti ih da i sami postanu vođe. West i kolege (2000, str. 39) navode sljedeće:

„Kako bi se rukovodstveni potencijal mogao ostvariti, potrebno je da on bude utemeljen na predanosti učenju i razvoju koja se mora osjetiti u strukturi škole i razreda - tada je izgledno da će škola razmišljati i djelovati drugačije od tradicionalnoga poimanja rukovodstva i strukture škole."

Glavni motiv za zainteresiranost za ispitivanje veze između nastavnika vođa i akademskih i neakademskih postignuća učenika jest ostvarivanje napretka u akademskom obrazovanju i naglašavanje ključne uloge obrazovnih djelatnika u tom procesu. Općenito govoreći, uglavnom se smatra da vođe imaju neizravan, ali snažan utjecaj na rezultate škole (Leithwood i Jantzi, 1999). Uspješni vođe utječu na kvalitetu nastavnoga procesa i motiviraju i učenike i kolege nastavnike te na taj način potiču i napredak škole (Sergiovanni, 2001). Kako navode Hallinger i Hell (1998), kvantitativna istraživanja o ravnateljima kao vođama pokazala su da oni imaju neizravan utjecaj na postignuća učenika, a taj utjecaj prolazi kroz nastavnike kao posrednike. Drugim riječima, nastavnici su primarni faktor koji utječe na rezultate škole.

Izravno nastavničko vodstvo u nastavi otvara im mogućnost preuzimanja važne uloge u mijenjanju okruženja za učenje kako bi se optimizirao proces učenja kod učenika. Slično tome, Katzenmeyer i Moller (2001) navode da nastavničko vodstvo povećava nastavnikova očekivanja, a samim time i poboljšava učenje kod učenika. Ryanu (1999) smatra da nastavnici imaju pozitivan utjecaj na proces učenja kod učenika, jer utječu na nastavnu praksu kolega i sudjeluju u donošenju odluka. Osim toga, Ovando (1996) smatra da nastavnici vođe pozitivno utječu na proces učenja kod učenika jer oni stvaraju i inovativno okruženje za učenje. Pellicer i Aderson (1995) navode da „nastavnici pomažu nastavnicima, pa onda nastavnici mogu bolje pomoći učenicima" (str. 22). Barth (1990) vjeruje da svi nastavnici imaju rukovodstveni potencijal te spominje potrebu za školama u kojima učenici, roditelji, nastavnici i ravnatelji svi mogu postati nastavnicima. Ravnatelj ima ključnu ulogu u stvaranju 
uvjeta koji omogućavaju nastavnicima da razviju rukovodstvene vještine (Buckner i McDowelle, 2000). Čak i Boles (1992) smatra da rukovodstvenu ulogu nastavnika oblikuje podrška koju im pruža ravnatelj, jaka organizacijska kultura, uključenost u proces donošenja odluka i profesionalno usavršavanje ostalih kolega.

Smatra se da je jedan od neakademskih ishoda škole na koje utječe nastavničko vodstvo zadovoljstvo učenika. Zadovoljstvo se može opisati kao ukupna razina užitka. Riječ zadovoljstvo uglavnom se koristi u teoriji hijerarhije potreba, koju je osmislio Abraham Maslow (1943). Kako smatra Maslow, zadovoljavanje osnovnih čovjekovih potreba pomoći će mu da dostigne više razine sigurnosti, ljubavi, pripadanja, poštovanja i samoostvarenja. Na temelju Maslowljeve teorije oni nastavnici u školi koji su prijateljski raspoloženi, pružaju podršku i provode najbolji nastavni proces, vode većoj razini zadovoljstva učenika (House, 2005; Suldo i sur., 2009). S druge strane, zadovoljstvo je važan aspekt uspjeha učenika, a velika razina zadovoljstva u pozitivnoj je vezi s visokim postignućima (Brown i sur., 2004).

Glavni razlog zbog kojega se pojam nastavničkoga vodstva i postignuća učenika dovodi u vezu sa zadovoljstvom jest taj što je potrebno ispitati vezu između njih, primjenom međukulturalne metaanalize objavljenih studija u Turskoj i SAD-u, što može pružiti holistički pogled na tu temu.

\section{Cilj istraživanja}

Cilj je ovoga istraživanja ispitati utjecaj nastavničkog vodstva na postignuća učenika i zadovoljstvo učenika u Turskoj i SAD-u. Koristila se metaanaliza kako bi se kvantitativno odredio utjecaj nastavničkog vodstva na postignuća učenika i na njihovo zadovoljstvo. Zemlja u kojoj je istraživanje provedeno koristila se kao moderatorska varijabla kako bi se objasnila varijacija u statističkim razlikama.

\section{Hipoteze istraživanja}

H1 Nastavničko vodstvo ima pozitivan utjecaj na postignuća učenika i na zadovoljstvo učenika.

H2 Država (Turska i SAD) u kojoj su nastale studije uključene u istraživanje moderatorska je varijabla za pozitivan utjecaj nastavničkog vodstva na postignuća učenika i zadovoljstvo učenika.

\section{Metodologija}

Metaanaliza je metoda kombiniranja rezultata višebrojnih, nezavisnih studija o određenoj temi, a koja primjenjuje statističku analizu dobivenih rezultata istraživanja. Ta metoda daje kvantitativne podatke te sažima rezultate različitih studija za istraživače koji donose konačni zaključak (Chin, 2007; Lipsey i Wilson, 2001; Robinson, Lloyd i Rowe, 2008).

Metaanaliza ima za cilj uključiti sve objavljene i neobjavljene podatke (disertacije, magistarske radove, članke, prijedloge, knjige) o određenoj temi. Međutim, u ovu 
studiju bile su uključene samo disertacije, magistarski radovi i članci objavljeni u recenziranim časopisima. Pregled literature proveden je u YOK-u (Vijeće za visoko obrazovanje u Turskoj), ULKBIM-u (Turska akademska mreža i informacijski centar) i u akademskim bazama ProQuest i EBSCO koje sadrže sažetke i sadržaj kvantitativnih istraživanja o nastavničkom vodstvu, postignućima učenika i zadovoljstvu učenika. Ključne riječi koje su se koristile u pretraživanju studija bile su: vođa, vodstvo, nastavnik vođa, postignuća učenika i zadovoljstvo učenika. Osim toga, u selekciji studija koje su se koristile u istraživanju primijenjeni su sljedeći kriteriji: datum kada su studije objavljene (između siječnja 2000. i prosinca 2017.), utjecaj nastavničkog vodstva na postignuća učenika i zadovoljstvo učenika, statistički podaci o veličini uzorka, Pearsonov $r$ za izračun veličine učinka i uzorak iz Turske ili SAD-a.

Kako bi se objavljeni radovi kategorizirali, bilo je neophodno izraditi okvir za razvoj sheme kodiranja za metaanalizu. Izrađena je knjiga s kodovima kako bi se izdvojili podaci iz literature. Studije koje su uključene u istraživanje bile su grupirane prema tome kako je procijenjen pristup nastavničkom vodstvu koji je prepoznat $\mathrm{u}$ istraživanju. U skladu s mišljenjem stručnjaka identificirane su moderatorske varijable te su u istraživanje uključene 34 veličine uzorka. Neke su studije isključene iz istraživanja jer su se isti setovi podataka koristili u nekoliko objavljenih radova. Međutim, nekoliko objavljenih radova uključenih u istraživanje ispitivalo je više od jednoga pristupa vodstvu. Zbog toga je određeno da set podataka koji se koristio u 22 objavljena rada uključuje ukupno 34 stavke. Dijagram tijeka odabira studija uključenih $\mathrm{u}$ istraživanje prikazan je na Prikazu 1.

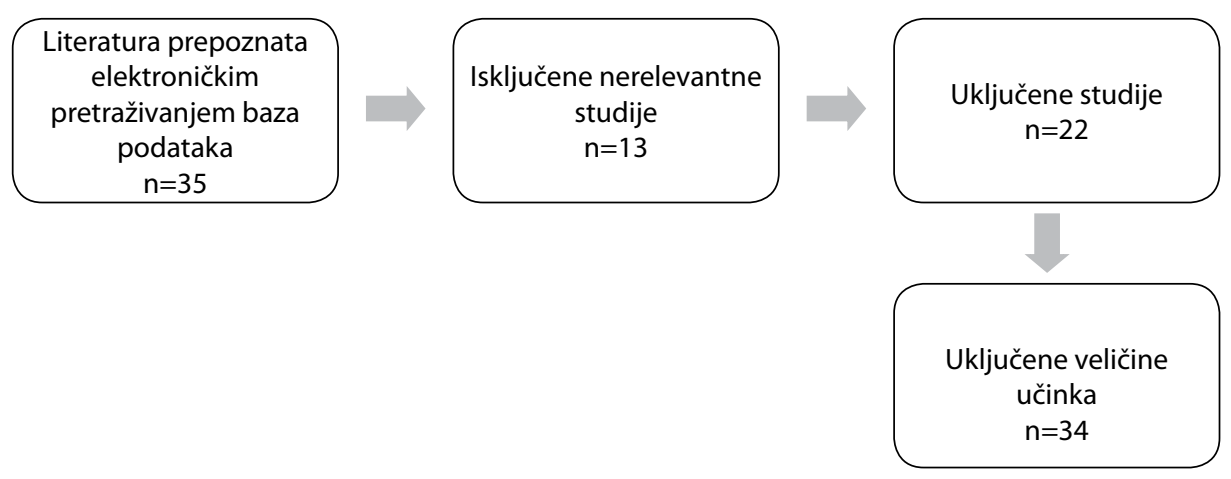

Prikaz 1. Dijagram tijeka koji prikazuje odabir studija za metaanalizu.

Veličina učinka može se zamisliti kao srednja razlika između grupa i koristiti u određivanju jačine, magnitude i smjera veze (Borenstein, Hedges, Higgins i Rothstein, 2009). Za Cohena, Maniona i Morrisona (2007, str. 221) vrijednosti veličine učinka na temelju korelacije interpretirane su na sljedeći način: $0 \leq$ veličina učinka $<0,10$ - mali učinak; $0,10 \leq$ veličina učinka $<0,30$ - skroman učinak; $0,30 \leq$ veličina učinka $<0,50$ umjeren učinak; $0,50 \leq$ veličina učinka $<0,80$ - jak učinak; veličina učinka $\geq 0,80$ jako snažan učinak. 
Postoje dva osnovna modela metaanalize: model fiksnoga učinka i model slučajnoga učinka. Kada se donosi odluka o tome koji će se model koristiti, potrebno je pregledati obilježja istraživanja koja će se koristiti u metaanalizi (Borenstein, Hedges, Higgins i Rothstein, 2009; Hedges i Olkin, 1985; Kulinskaya, Morgenthaler i Staudte, 2008). Model fiksnoga učinka procjenjuje se primjenom najveće vjerojatnosti (sve studije koje su obuhvaćene metaanalizom funkcionalno su identične) i izračunom veličine učinka za definiranu populaciju. Za razliku od toga nije vjerojatno da su sve studije funkcionalno ekvivalentne, a generalizacije se mogu primijeniti na veću populaciju gdje je model slučajnoga učinka pogodniji od modela fiksnoga učinka (Karadağ, Bektaş, Çoğaltay i Yalçın, 2015). U istraživanju se najprije koristio model fiksnoga učinka, no uočeno je da se homogenost nije mogla postići primjenom toga modela (ovisno o rezultatima testa heterogenosti, istraživanje nije isto s obzirom na funkcionalnost, $\left(\mathrm{Q}>\mathrm{X}^{2}\right)$, vidi Tablicu 3) pa je primijenjen model slučajnoga učinka. Razina značajnosti od 0,05 određena je za sve statističke izračune u istraživanju.

Moderatorska analiza je metoda koja omogućava testiranje razlika između srednje vrijednosti veličine učinka varijabli (moderatora) i smjera razlika između podskupina. Statistička značajnost razlika između moderatorskih varijabli testirana je s pomoću Q statističke metode koju su izradili Hedges i Olkin (1985). U toj metodi se Q dijeli na $\mathrm{Q}$ između $[\mathrm{Qb}]$ i $\mathrm{Q}$ unutar $[\mathrm{Qw}]$, a analize se provode na te dvije različite vrijednosti Q. Qw testira homogenost same moderatorske varijable, a Qb testira homogenost među skupinama (Borenstein, Hedges, Higgins i Rothstein, 2009; Hedges i Olkin, 1985; Kulinskaya, Morgenthaler i Staudte, 2008). U ovom istraživanju samo su se Qb vrijednosti koristile za statističku značajnost razlika između moderatora.

\section{Rezultati}

U ovome je dijelu provedena deskriptivna analiza studija, a zatim su dobiveni podaci kombinirani s pomoću metaanalize. Podaci koji se odnose na studije prikazani su u sljedećoj tablici upotrebom frekvencija i postotaka. Tablica 1 prikazuje deskriptivnu analizu studija obuhvaćenih $u$ istraživanju.

\section{Tablica 1}

Tablica 1 pokazuje da je 26 studija provedeno u Turskoj, a u SAD-u ih je provedeno samo 8. Datum distribucija studija pokazuje da je većina njih $(82,3 \%)$ provedena 2009. godine i poslje. To ukazuje na činjenicu da je u posljednjih nekoliko godina nastavničko vodstvo postalo temom koja je istraživačima jako zanimljiva. Otprilike $60 \%$ studija napisano je u obliku disertacije.

\section{Tablica 2}

Kako se može vidjeti u Tablici 2, smjer veličine učinka pozitivan je za većinu studija $(94,1 \%)$ uključenih u istraživanje.

Tablica 3 
Vrijednost veličine učinka (srednja vrijednost $r$ ) izračunata je kako bi se odredila jačina i smjer veze između nastavničkog vodstva i postignuća učenika i zadovoljstva učenika (Tablica 3). Koeficijent korelacije (r) pretvoren je u Fischerov z (Hedges i Olkin, 1985), naveden u tablici 3. Kada se veličina učinka izračuna, interpretira se s pomoću Cohenovih vrijednosti kriterija. Kako pokazuju rezultati metaanalize u kojoj se koristio model fiksnoga učinka, vrijednost za nastavničko vodstvo s obzirom na utjecaj na postignuća učenika iznosila je 0,249 za Tursku i 0,115 za SAD. Rezultat za obje zemlje bio je 0,229 . Osim toga, vrijednost za zadovoljstvo učenika iznosila je 0,691 za Tursku i 0,169 za SAD. Za obje zemlje vrijednost veličine učinka bila je 0,639. Taj rezultat potvrđuje hipotezu H1 u kojoj se navodi da nastavničko vodstvo ima pozitivan utjecaj na postignuća učenika i zadovoljstvo učenika. Ovisno o rezultatima testa heterogenosti, istraživanje nije isto $s$ obzirom na funkcionalnost, pa se model slučajnoga učinka primjenjivao $u$ daljnjim postupcima metaanalize $\left(\mathrm{Q}>\mathrm{X}^{2}\right)$.

\section{Tablica 4}

Rezultati idu u prilog Hipotezi 2, kojom se tvrdi da je država (Turska i SAD) u kojoj su objavljene studije koje su poslije uključene u istraživanja moderatorska varijabla pozitivnog utjecaja nastavničkog vodstva na postignuća učenika i zadovoljstvo učenika (Tablica 4). Pokazalo se da država kao moderatorska varijabla objašnjava pretjeranu varijabilnost veličine učinka. Ta je veličina učinka u Turskoj i za postignuća i zadovoljstvo $(0,252 / 0,488)$ znatno veća od veličine učinka u SAD-u $(0,171 / 0,169)$.

\section{Rezultati povezani sa sustavnim pogreškama u objavljivanju}

Uistinu je od ključne važnosti kontrolirati sustavne pogreške u objavljivanju tijekom provedbe metaanalize. Te sustavne pogreške temelje se na pretpostavci da još uvijek nisu objavljena sva istraživanja o nekoj temi. Kako se smatra da nije potrebno objavljivati istraživanja u kojima se nisu uočile statistički značajne veze ili u kojima su prepoznate niske razine veza, to utječe na ukupnu veličinu učinka na negativan način i na pristran način povećava srednju veličinu učinka (Borenstein, Hedges, Higgins i Rothstein, 2009). U tom smislu se u studijama koje uključuju metaanalizu u obzir uzima i vjerojatnost da postoje sustavne pogreške u objavljivanju. Koriste se brojne metode izračunavanja kako bi se došlo do statističkog odgovora na pitanje postoje li u metaanalizi sustavne pogreške u objavljivanju ili ne postoje. Metoda grafikona lijevka jedna je od njih. Oblik koji se tom metodom dobiva pokazuje postoje li u studijama dobivenim subjektivnom procjenom sustavne pogreške u objavljivanju. U ovome se istraživanju koristio grafikon lijevka istraživanja obuhvaćenih metaanalizom (Prikaz 2).

Prikaz 2.

Na Prikazu 2 nema dokaza o sustavnim pogreškama u objavljivanju u studijama obuhvaćenim metaanalizom. Može se očekivati da će grafikon lijevka biti značajno asimetričan u sustavnim pogreškama u objavljivanju. Koncentracije koje su na jednoj 
strani linije veće i pokazuju prosječnu veličinu učinka, pogotovo u donjim dijelovima lijevka, ukazuju na mogućnost postojanja sustavnih pogrešaka u objavljivanju. Nisu pronađeni dokazi da postoje sustavne pogrješke u objavljivanju kod 34 studije obuhvaćene metaanalizom istraživanja.

Iako ne postoji dokaz o sustavnim pogreškama u grafikonu lijevka, rezultati Oduzmi i dodaj (eng. Trim and Fill) testa prikazani su u Tablici 5 kako bi se procijenila veličina učinka metaanalize modelom slučajnoga učinka, $s$ obzirom na sustavne pogreške $u$ objavljivanju.

\section{Tablica 5}

Kako se može vidjeti u Tablici 6, ne postoji razlika između jačine promatranoga učinka i virtualnoga učinka. Klasična analiza Sigurno neznačajni N (eng. Fail-Safe N) također je provedena kako bi se analizirale sustavne pogreške u objavljivanju. Rezultati analize prikazani su u Tablici 6 .

Prema dobivenim rezultatima u analizu bi trebalo dodati još 9245 pojedinačnih studija kako bi se poništio rezultat metaanalize $(\mathrm{p}<0,05)$. Taj podatak pokazuje da $\mathrm{u}$ metaanalizi ne postoji sustavna pogreška.

\section{Rasprava i zaključak}

Cilj ovoga istraživanja bio je ispitati utjecaj nastavničkog vodstva na postignuća i zadovoljstvo učenika. Rezultati metaanalize pokazali su da nastavničko vodstvo ima blag pozitivan utjecaj na postignuća učenika i jak pozitivan utjecaj na zadovoljstvo učenika. U Turskoj je utjecaj nastavničkog vodstva na zadovoljstvo učenika puno jači nego u SAD-u.

Prije rasprave o rezultatima ovoga istraživanja bitno je objasniti i njegova ograničenja. U analizu su uključene samo 22 studije, jer preostale studije nisu imale potrebne podatke za izračun prosječne veličine. Također je potrebno više istraživanja kako bi se provela analiza drugih neakademskih rezultata povezanih s učenicima, osim njihova zadovoljstva.

U literaturi se može primijetiti da nastavničko vodstvo ima utjecaja na postignuća učenika (Lambert, 1998; Leiberman i Miller, 2004; Murphy, 2005; Smylie, 2010; Spillane, 2006). Kako nastavnici imaju informacije o okruženju za učenje u svojim učionicama, oni su u povoljnom položaju za donošenje učinkovitih rješenja (Sinclair, 1992). Nastavnici čak imaju i važnu ulogu u razvoju okruženja za učenje putem rješavanja različitih problema koji se javljaju u nastavi te stvaraju školsku kulturu koja pruža podršku svojim učenicima (Francis, Hirsch i Rowland, 1994). K tomu, Stigler i Hiebert (1999) objašnjavaju da nastavnici koji surađuju s kolegama, ravnateljima i ostalim dionicima, doprinose poboljšanju procesa učenja kod učenika. Allen i njegovi kolege (2011) naveli su pozitivne utjecaje nastavnika vođa na učenička postignuća. Leithwood i Mascall (2008) došli su do sličnih pozitivnih rezultata ponašanja nastavnika vođa. Isto tako, Silns i Mumford (2002) smatraju da je osnaživanje nastavnika neophodno za razvoj učeničkih postignuća. 
Dakle, što je potrebno kako bi se ostvario puni potencijal nastavnika vođa? Odgovor je: ravnatelj škole. Ravnatelji su odgovorni za dijeljenje ili raspodjelu rukovodećih zaduženja. Iako se u mnogim istraživanjima može pročitati da ravnatelji kao rukovoditelji imaju utjecaj na uspjeh škole (Leithwood, Jantzi i Steinbach 1999; Marzano, Waters i McNulty, 2005), u posljednje se vrijeme sve više ide u prilog stavu da nastavnici vođe imaju takav utjecaj, za razliku od tradicionalnih uvjerenja (Copland, 2003). Kako navode Angelle i DeHart (2010), „Ravnatelji moraju mijenjati svoje viđenje nastavnika kao sljedbenika te ih prihvatiti kao pomoćnike" (str. 8).

Zadovoljstvo nastavnika i zadovoljstvo učenika u pozitivnoj je korelaciji s postignućima učenika (Caprara, Barbranelli, Steca i Malone, 2006; Lim, Kim, Chen i Ryder, 2008). Osim toga, niska razina zadovoljstvo rezultira slabijim akademskim postignućima učenika (Brown, Anfara i Roney, 2004; Van Houtte, 2006). Pristupačni nastavnici koji se koriste raznovrsnim nastavnim metodama pomažu učenicima kako bi poboljšali školski uspjeh, a to dovodi do veće razine učeničkog zadovoljstva (Suldo i sur., 2006, str. 80). U studiji koji je proveo Baird (1973), rezultati pokazuju da nastavnici koji surađuju s učenicima razvijaju i učenička postignuća i njihovo zadovoljstvo.

Usporedba rezultata dobivenih u Turskoj i onih dobivenih u SAD-u pokazala je da je prosječna veličina učinka veća u Turskoj. Centralizirani obrazovni sustav u Turskoj mogao bi biti jedan od bitnih čimbenika odgovornih za tu razliku. Iako je nastavničko vodstvo česta tema istraživanja koja se provode u Turskoj, taj pojam se ne primjenjuje. Uzimajući u obzir dinamiku nastavničkog vodstva, sudjelovanje u donošenju odluka, osmišljavanje nastave i razvoj kurikula, od ključne je važnosti pružiti podršku nastavnicima kako bi se optimizirala učinkovitost škola.

Iako se iz literature može jasno zaključiti da je nastavničko vodstvo neophodno za učinkovitu školu, postoje prepreke koje je potrebno savladati. Kako bi se razvijalo i poticalo nastavničko vodstvo, preporučujemo sljedeće:

Vrstu rukovođenja koje se provodi od vrha prema dolje i koja zadržava birokratsku i hijerarhijsku strukturu treba zamijeniti organizacijom koja uvodi zajedničko vodstvo.

Mogli bi se definirati zajednički obrazovni standardi koji nastavnicima omogućuju sudjelovanje u procesu donošenja odluka vezanih uz kurikul i nastavu.

Različiti oblici stručnoga usavršavanja, poput radionica, trebali bi uključivati vještine kao što su preuzimanje vodstva u skupini, suradnički rad i mentoriranje. Na taj bi se način moglo razvijati nastavničko vodstvo. 